\title{
Особливості синтезу білка у міцелії Pleurotus ostreatus за дії лазерного опромінення
}

\section{Катерина Решетник}

Донецький національний університет імені Василя Стуса, Вінниця, Україна

Адреса для листування: k.reshetnyk@donnu.edu.ua

Резюме. Базидієві гриби - цінні біологічні об’єкти, які використовують для отримання біологічно активних речовин. Метою нашої роботи було вивчення впливу лазерного опромінення на накопичення біомаси та процеси синтезу білка у міцелії Pleurotus ostreatus. Для дослідження були використані штами гриба P. ostreatus iз Колекції культур базидієвих грибів кафедри ботаніки та екології Донецького національного університету імені Василя Стуса. Опромінення інокулюму розміром близько $5 \times 5$ мм (завжди однієї щільності й віку) проводили перед посівом за допомогою світлодіодних лазерів: BRP3010-5 (довжина хвилі 635 нм), ВBР-3010-5 (довжина хвилі 405 нм) та BGP-3010-5 (довжина хвилі 532 нм). Потужність кожного лазера становила 100 мВт. Енергія опромінення у всіх варіантах досліду становила 51,1м Дж/см². Рівень накопичення біомаси визначали ваговим методом, висушуючи міцелій до постійної маси при температурі $(105 \pm 1)^{\circ} \mathrm{C}$. 3 метою визначення кількості білка застосовували метод біуретової реакції. Отримані результати дослідження засвідчують вплив лазерного опромінення на стимуляцію ростових та біосинтетичних процесів P. ostreatus. Зокрема, для P. ostreatus найефективнішим було опромінення зеленим світлом довжиною хвилі 532 нм. За дії цього режиму опромінення найкращу реакцію у відповідь на дію світла спостерігали для штаму Р-192 - кількість біомаси зросла на 71,4\%. Було встановлено зростання кількості білка у міцелії P. ostreatus за дії лазерного опромінення. Для штаму Р-192 гриба P. ostreatus вміст загального білка зріс на 36,3\% відповідно до контролю за дії опромінення зеленим світлом (532 нм). Одержані результати показують перспективність використання лазерного опромінення світлом у зеленому діапазоні для цілеспрямованої регуляції синтезу білка та біомаси міцелію гриба $P$. ostreatus.

Ключові слова: Pleurotus ostreatus, біомаса, білок, поверхневе культивування, фотоактивація.

\section{Peculiarities of protein synthesis in Pleurotus ostreatus mycelium for laser irradiation}

\section{Kateryna Reshetnyk}

Vasyl' Stus Donetsk National University

Correspondence: k.reshetnyk@donnu.edu.ua.

\begin{abstract}
Features of protein synthesis in the mycelium of Pleurotus ostreatus under the action of laser irradiation. Kateryna Reshetnyk.

Basidiomycetes are valuable biological objects that are used to produce biologically active substances. The aim of our work was to study the effect of laser irradiation on biomass accumulation and protein synthesis processes in Pleurotus ostreatus mycelium. Strains of the fungus $P$. ostreatus from the Collection of cultures of basidiomycetes of the Department of Botany and Ecology of Vasyl' Stus Donetsk National Universitywere used for the study. Irradiation of the inoculum with a size of about $5 \times 5 \mathrm{~mm}$ (always of the same density and age) was performed before sowing using LED lasers: BRP-3010-5 (wavelength $635 \mathrm{~nm}$ ), BBP-3010-5 (wavelength $405 \mathrm{~nm}$ ) and BGP-3010-5 (wavelength $532 \mathrm{~nm}$ ). The power of each laser was $100 \mathrm{~mW}$. The irradiation energy in all variants of the experiment was $51.1 \mathrm{~mJ} / \mathrm{cm}^{2}$. The level of biomass accumulation was determined by weight method, drying the mycelium to constant weight at a temperature of $(105 \pm 1)^{\circ} \mathrm{C}$. In order to determine the amount of protein used the method of biuret reaction. Our research results indicate the effect of laser irradiation on the stimulation of growth and biosynthetic processes of $P$. ostreatus. In particular, for $P$. ostreatus, green light irradiation with a wavelength of $532 \mathrm{~nm}$ was the most effective. Under the action of this irradiation regime, the


best reaction in response to light was observed for strain P-192 - the amount of biomass increased by $71.4 \%$. An increase in the amount of protein in the mycelium of $P$. ostreatus was found under the action of laser irradiation. For strain P-192 of the fungus $P$. ostreatus, the total protein content increased by $36.3 \%$ in accordance with the control over the effects of green light irradiation $(532 \mathrm{~nm})$. Our results show the prospects of using laser irradiation with light in the green range for targeted regulation of protein synthesis and biomass of mycelium of the fungus $P$. ostreatus.

Key words: Pleurotus ostreatus, biomass, protein, surface cultivation, photoactivation.

\section{ВСТУП}

Станом на цей час базидієві гриби є цінними біологічними об'єктами, які використовують для отримання біологічно активних речовин. Pleurotus ostreatus (Jacq.) P. Kumm .містить сполуки, які здатні попереджати й лікувати широкий спектр захворювань. Зокрема, дослідження показали, що високий вміст чистого протеїну (до 47,7\%) у плодових тілах $P$. ostreatus, сприяє запобіганню та лікуванню гепатиту, виразки шлунка, знижує кількість холестерину в крові, допомагає нормалізувати тиск як у гіпертоніків, так і в гіпотоніків, надає протипухлинну дію, підвищує імунну стійкість організму [1]. У статті О. М. Алексєєнка зі співавторами досить добре проаналізовано та узагальнено харчові й лікувальні властивості плодових тіл грибів P. ostreatus. Зокрема, встановлено, що в білках плодових тіл гливи $\epsilon$ 18 амінокислот, 8 із них незамінні (ізолейцин, лейцин, лізин, метіонін, фенілаланін, триптофан, треонін, валін) [2].

Встановлено, що, культивуючи грибний міцелій на живильному середовищі, яке має у своєму складі, наприклад, целюлозу, можна отримати $20 \%$ від сухої маси вмісту білка в міцелії. Якщо використовувати оптимізоване за кількістю необхідних компонентів живильне середовище, то вміст білка в грибній біомасі може сягати до $30 \%$, цей показник є більшим, ніж у багатьох овочів та злакових культур. Загалом для покращення кількості міцеліального білка застосовують традиційні підходи, зокрема вплив джерел вуглецю, азоту, мікроелементів та різних органічних добавок [3]. 3 літературних джерел відомо, що склад середовища, на якому відбувається культивування грибів, та способи культивування $є$ досить суттєвими факторами, які визначають вплив різних чинників на ростові та біосинтетичні процеси грибів $[4,5]$. Одним із таких чинників є світло, яке регулює ростові та біосинтетичні процеси в багатьох видів грибів. Характер впливу світла залежить від його спектральних характеристик та від тривалості освітлення [6]. На сьогодні відомий вплив низькоінтенсивного світла на лінійний ріст та накопичення біомаси різними видами грибів: Agaricus bisporus (J.E. Lange) Imbach, Hericium erinaceus (Bull.) Persoon, Inonotus obliguus (Fr.) Pilat, Lentinula edodes (Berk.) Pegler [7]. Проте літературні дані щодо впливу лазерного опромінення на фізіологічні параметри росту грибів обмежені, тому це питання потребує подальшого вивчення. Враховуючи вищезазначене, метою нашої роботи було вивчення впливу лазерного опромінення на накопичення біомаси та процеси синтезу білка в міцелії $P$. ostreatus.

\section{МАТЕРІАЛИ І МЕТОДИ}

Дослідження проводили на кафедрі ботаніки та екології Донецького національного університету імені Василя Стуса (ДонНУ імені Василя Стуса). Для дослідження були використані штами гриба P.ostreatus iз Колекції культур базидієвих грибів кафедри ботаніки та екології ДонНУ імені Василя Стуса. Для отримання інокулюму міцелій штамів Р191, Р-192, Р-6v, P-154, Р-155, Р-108 гриба P. ostreatus культивували на агаризованому глюкозо-пептонному середовищі (ГПСА), г/л: глюкоза - 10,0; пептон - 3,0; $\mathrm{KH}_{2} \mathrm{PO}_{4}-0,6$; $\mathrm{K}_{2} \mathrm{HPO}_{4}-0,4 ; \mathrm{MgSO}_{4} 7 \cdot \mathrm{H}_{2} \mathrm{O}-0,5 ; \mathrm{CaCl}_{2}-0,05$; $\mathrm{ZnSO}_{4} \cdot 7 \mathrm{H}_{2} \mathrm{O}-0,001$, дистильована вода - до 1 дм³ $^{3}$ агар-агар - 15 у чашках Петрі за температури $28 \pm 1{ }^{\circ} \mathrm{C}$. Під час дослідження впливу лазерного опромінення міцелію у поверхневій культурі використовували глюкозо-пептонне рідке живильне середовище (ГПС) ), г/л: глюкоза - 10,0; пептон - 3,0; $\mathrm{KH}_{2} \mathrm{PO}_{4}-0,6 ; \mathrm{K}_{2} \mathrm{HPO}_{4}-0,4 ; \mathrm{MgSO}_{4} 7 \cdot \mathrm{H}_{2} \mathrm{O}-0,5$; $\mathrm{CaCl}_{2}-0,05 ; \mathrm{ZnSO}_{4} \cdot 7 \mathrm{H}_{2} \mathrm{O}-0,001$, дистильована вода - до 1 дм $^{3}$. Міцелій культивували впродовж 12 діб за температури $28 \pm 1^{\circ} \mathrm{C}$ у термостаті в колбах Ерленмеєра об`ємом 250 мл, що містили 50 мл живильного середовища ГПС. Інокуляцію проводили дисками міцелію культур, що були вирощені на ГПСА. По п’ять дисків діаметром 5 мм вирізали стерильною сталевою трубкою на відстані 8-10 мм від краю активного росту колонії.

Для лазерного опромінення вегетативного міцелію використовували пристрій, який був сконструйований співробітниками кафедри 
Науковий вісник Східноєвропейського національного університету імені Лесі Українки. Серія: Біологічні науки, 2020, 2 (390)

ботаніки та екології ДонНУ імені Василя Стуса (Рис. 1).

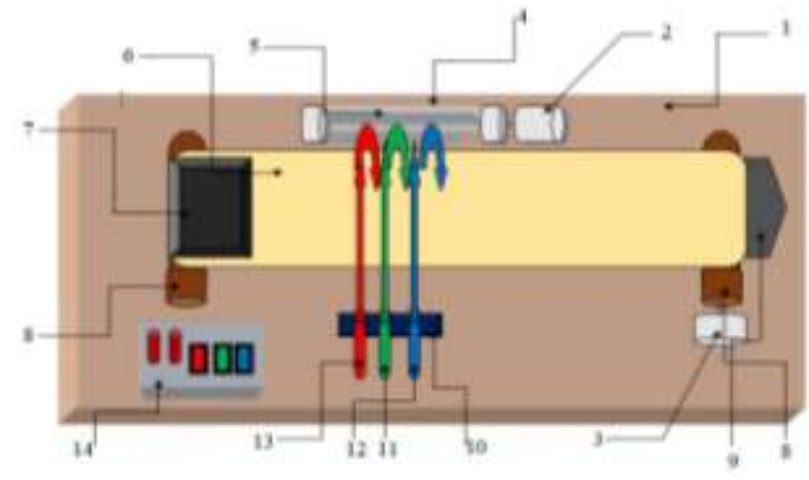

Рис. 1. Пристрій для опромінення міцелію монохроматичним світлом за допомогою LED лазерів.

1 - платформа для кріплення пристрою, 2- електродвигун 1, 3 - електродвигун 2, 4 захисна кришка для дзеркальної призми, 5 дзеркальна призма, 6 - транспортерна стрічка, 7 - бункер для опромінених обє'ктів, 8 - валик, який рухає транспортерну стрічку, 9 платформа для опромінених обє'ктів, 10 штатив для кріплення LED лазерів, 11 - LED лазер ВGP-3010-5 з випромінюванням зеленого спектру з довжиною хвилі 532 нм, 12 - LED лазер ВВР-3010-5 з випромінюванням синього спектру з довжиною хвилі 405 нм, 13 - LED лазер BRP-3010-5, з випромінюванням червоного спектру з довжиною хвилі $635 \mathrm{mм}, 14$ - панель управління.

Міцелій опромінювали у такий спосіб: чашка Петрі 3 міцелієм рухається на транспортерній стрічці під променем світла зі встановленою довжиною хвилі: 635, 405 та 532 нм, отримуючи необхідну енергію

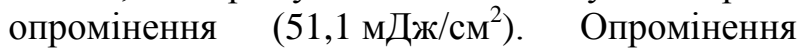
міцелію тривало 10 с. Потім за допомогою стерильної сталевої трубки 3 колонії міцелію вирізали міцеліальні диски діаметром 5 мм та здійснювали інокуцяцію на рідке живильне середовище (ГПС) відповідного складу. Для інокуляції контрольних чашок Петрі застосовували неопромінену культуру. Опромінення міцелію проводили в декількох варіантах (табл. 1).

Рівень накопичення біомаси визначали ваговим методом, висушуючи міцелій до постійної маси при температурі $(105 \pm 1)^{\circ} \mathrm{C}$ [8].

Для визначення кількості білка міцелій відділяли від культурального фільтрату за допомогою паперового фільтра. Підготовлений міцелій гриба в кількості 1 г гомогенізували в ступці з додаванням 10 мл дистильованої води (для альбумінів) або $10 \%$ розчину $\mathrm{NaCl}$ (для глобулінів) та відцентровували в центрифузі при 2500 об/хв. Для визначення кількості білка застосовували метод біуретової реакції. В першу пробірку вносили 0,1 мл дистильованої води (контроль), у другу - 0,1 мл стандартного розчину білка $\left(50\right.$ г/дм $\left.{ }^{3}\right)$, в інші пробірки - по 0,1 мл досліджуваного розчину білка. У кожну пробірку додавали по 5 мл біуретового реактиву, перемішували, витримували 30 хв при кімнатній температурі. Виміряли оптичну щільність калібрувальної або дослідної проби проти холостої проби, при довжині хвилі (540 560 нм) в діапазоні 0-1.0 од. опт. щільності. Аналіз проводили згідно зі схемою (табл. 2).

\section{Схема опромінення міцелію гриба Pleurotus ostreatus}

\section{Таблиия 1}

\begin{tabular}{|c|c|c|c|c|}
\hline \multirow{2}{*}{$\begin{array}{c}\text { Варіант } \\
\text { опромінення }\end{array}$} & \multicolumn{3}{|c|}{ Тривалість опромінення, с } & \multirow{2}{*}{$\begin{array}{c}\text { Енергія } \\
\text { опромінення, } \\
\text { мДж/см }{ }^{2}\end{array}$} \\
\cline { 2 - 5 } & $\begin{array}{c}\text { Червоне світло } \\
\text { (довжина хвилі 635 нм) }\end{array}$ & $\begin{array}{c}\text { Синє світло } \\
\text { (довжина хвилі 405 нм) }\end{array}$ & $\begin{array}{c}\text { Зелене світло } \\
\text { (довжина хвилі 532 нм) }\end{array}$ & 0 \\
\hline 1 (контроль) & 0 & 0 & 0 & 51,1 \\
\hline 2 & 10 & 0 & 0 & 51,1 \\
\hline 3 & 0 & 10 & 10 & 51,1 \\
\hline 4 & 0 & 0 & 0 & 0 \\
\hline
\end{tabular}

\section{Схема проведення досліду}

Табличя 2

\begin{tabular}{|c|c|c|c|c|c|c|}
\hline \multirow{2}{*}{} & \multicolumn{9}{|c|}{ Кількість розчину, мл } \\
\cline { 2 - 7 } & \multicolumn{2}{|c|}{ Калібрувальна чи дослідна проба } & \multicolumn{3}{c|}{ Холоста проба } \\
\cline { 2 - 7 } & Макро & Напівмікро & Мікро & Макро & Напівмікро & Мікро \\
\hline $\begin{array}{c}\text { Калібрувальний чи } \\
\text { дослідний розчин }\end{array}$ & 0,08 & 0,04 & 0,02 & - & - & 0,04 \\
\hline Фізіологічний розчин & - & - & - & 0,08 & 0,04 & 1,00 \\
\hline Біуретовий реактив & 4,00 & 2,00 & 1,00 & 4,00 & 2,00 & 1,00 \\
\hline
\end{tabular}


Розрахунок концентрації загального білка проводили за формулою:

$$
C=\frac{E_{\partial o c}}{E_{\text {кал }}} \times 50, \text { де: }
$$

С - концентрація загального білка в дослідній пробі, г/дм³;

50 - концентрація загального білка в калібрувальному розчині, г/дм³ ;

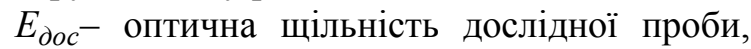
од. опт. щільності;

$E_{\text {кал }}-$ оптична щільність калібрувальної проби, од. опт. щільності.

Усі досліди проводили в трикратній повторюваності. Для визначення вірогідності впливу лазерного опромінення на кількість біомаси та білка застосовували метод дисперсійного аналізу. Порівняння середніх значень здійснювали методом Даннета [9]. Обробку проводили за допомогою пакета статистичних програм [10].

\section{РЕЗУЛЬТАТИ ТА ОБГОВОРЕННЯ}

Аналіз результатів наших досліджень засвідчує позитивний вплив опромінення на накопичення біомаси досліджуваними штамами гриба. Зокрема, для P. ostreatus найефективнішим було опромінення зеленим світлом довжиною хвилі $532 \mathrm{Hм}$ (енергетична доза

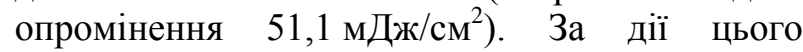
режиму опромінення найкраща реакція у відповідь на дію світла спостережена для штаму Р-192 - кількість біомаси зросла на 71,4\% відповідно до контролю. Для штамів Р-
191 та Р-155 біомаса зросла на 60\% та на 53,5\% відповідно. Для штамів Р-108, Р-154 та Р-6v показник кількості біомаси зростав від 33,3 до $50 \%$ відповідно. Лазерне опромінення червоним світлом довжиною хвилі $635 \mathrm{нм}$ (енергетична доза опромінення 51,1 мДж/см²) призвело до зростання біомаси для всіх досліджених штамів у межах від 16\% до 25\%, а для штаму P-155 цей показник збільшився на $35,7 \%$. Опромінення міцелію синім світлом довжиною хвилі 405 нм (енергетична доза

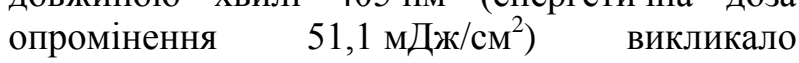
зростання біомаси міцелію для всіх досліджених штамів P. ostreatus в межах від 11,9 до 31,2\% відповідно (Рис. 2).

Нами вперше проведено дослідження можливості використання опромінення когерентним світлом різної довжини хвилі як фактора регуляції синтезу білка у міцелії P. ostreatus. Зокрема, встановили зростання кількості білка у міцелії P. ostreatus за дії лазерного опромінення. Для штаму Р-192 гриба P. ostreatus вміст загального білка зріс на $36,3 \%$ відповідно до контролю за дії опромінення зеленим світлом (532 нм) (енергетична доза

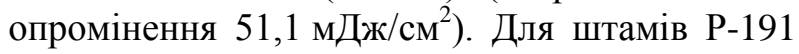
та Р-155 вміст білка збільшився на $32,3 \%$ та на $32,9 \%$ відповідно за дії цього ж режиму опромінення. Для штамів Р-108, P-154 та Р-6v показник кількості білка зростав від 24,5 до $32,5 \%$ відповідно. Лазерне опромінення червоним світлом (635 нм) (енергетична доза

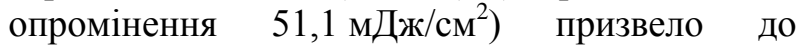
зростання вмісту білка для всіх досліджених штамів у межах від $6,3 \%$ до $14,8 \%$.

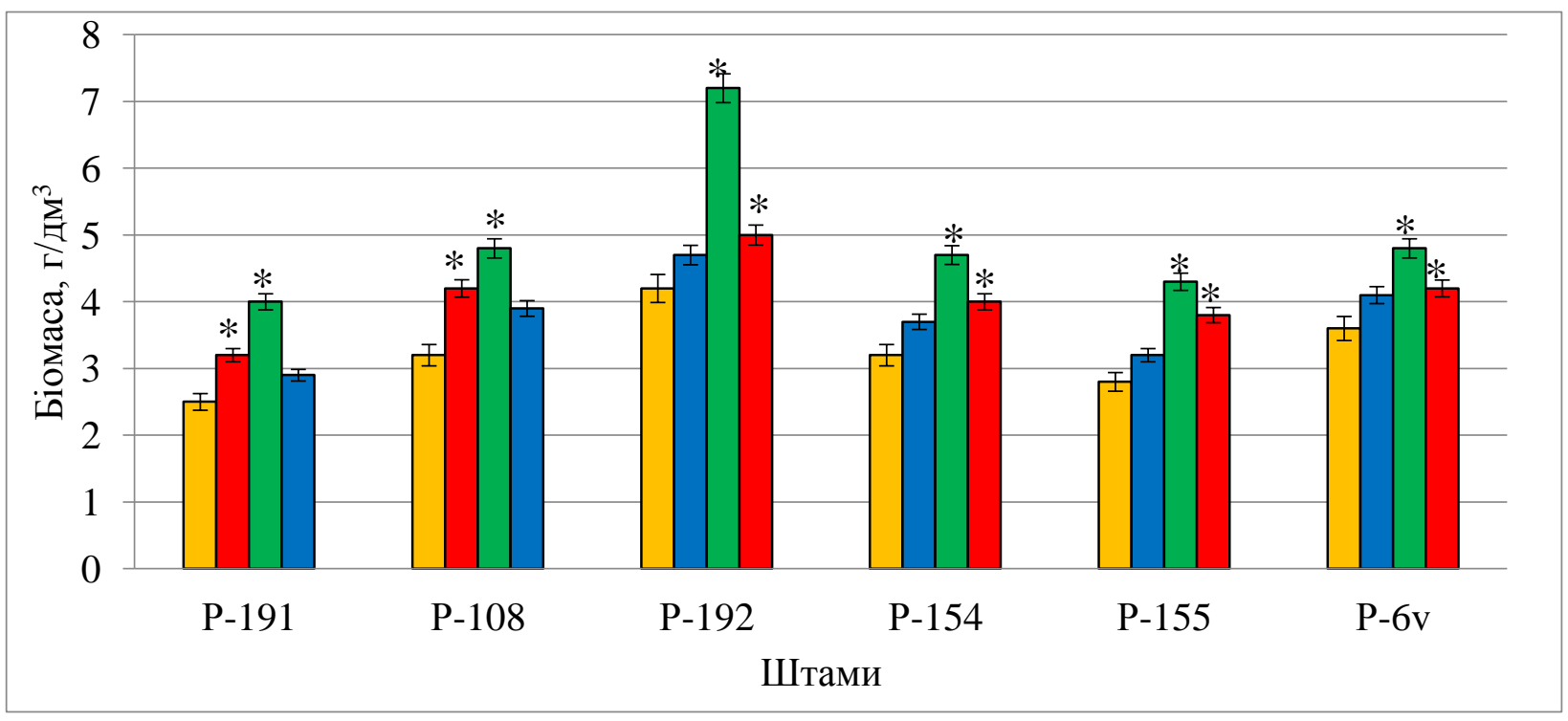

Рис. 2. Накопичення мічеліальної біомаси штамів Pleurotus ostreatus за дії лазерного опромінення при культивуванні на глюкозо-пептонному середовищі. 12 доба культивування.

- без опромінення; $\square-405$ нм; $\square-635$ нм; $\square-532$ нм. *-P<0,05 порівняно з контролем. 


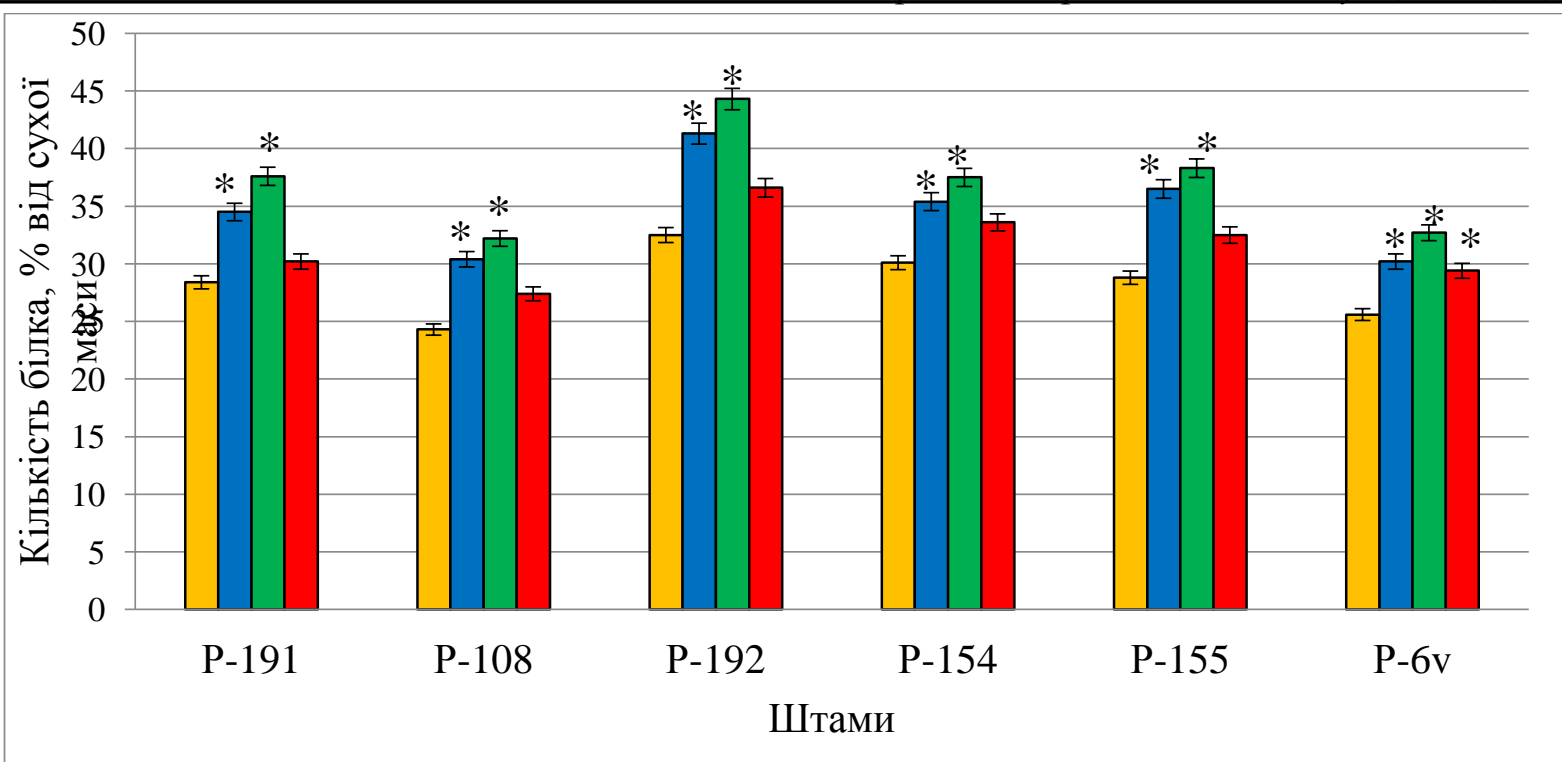

Рис. 3. Кількість білка у міцелії штамів Pleurotus ostreatus при культивуванні на глюкозопептонному середовищі за дії лазерного опромінення. 12 доба культивування.

- без опромінення; $\square-405 \mathrm{\mu м} ; \square-635 \mathrm{\mu м} ; \square-532 \mathrm{\mu м.} *-P<0,05$ порівняно з контролем.

Опромінення міцелію синім світлом довжиною хвилі 405 нм (енергетична доза

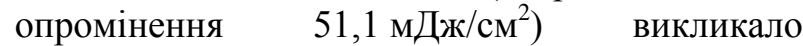
зростання білка міцелію для всіх досліджених штамів P ostreatus у межах від 17,6 до $27 \%$ відповідно (рис. 3).

Відомо, що Н. Л. Поєдинок було вивчено накопичення біомаси базидієвих грибів на рідкомуглюкозо-пептонному середовищі 3 різними концентраціями глюкози $(10,30$ i 50 г/дм $\left.{ }^{3}\right)$ при використанні посівного міцелію (5\% об'єму), опроміненого низькоінтенсивним червоним світлом (632,8 нм). Культивування проводили в стаціонарному режимі. У всіх досліджених штамів найбільш стимулюючий ефект після опромінення спостерігався при рості на середовищі з 10 г/л глюкози Зростання концентрації глюкози в 3 і 5 разів знижувало збільшення накопичення біомаси порівняно 3 контролем у H. erinaceus на 19 і $31 \%$ та в P. ostreatusна 10 і 23\% відповідно [11].

Отримані результати дослідження засвідчують вплив лазерного опромінення на стимуляцію ростових та біосинтетичних процесів P. ostreatus. Пояснення цих результатів вбачаємо в тому, що лазерне світло може відновлювати мембранний та генетичний апарат клітини, активувати ферменти антиперекисного захисту шляхом підвищення антиоксидантного та протекторного захисту. Це призводить до стимуляції зростання синтезу нуклеїнових кислот, структурних білків та білків регуляторів $[12,13]$.

Нами вперше встановлено ефективність використання лазерного опромінення як Розділ I. Ботаніка фактора регуляції синтезу білка у міцелії $P$. ostreatus. Найефективнішим є використання опромінення зеленим світлом (532 нм) - вміст білка збільшився на $36,3 \%$ (штам Р-192). Доведено ефективність використання лазерного опромінення зеленим світлом міцелію гриба $P$. ostreatus для отримання біомаси у всіх досліджених штамів. Найпродуктивнішим за накопиченням біомаси виявився штам Р-192 кількість біомаси зросла на 71,4\%. Одержані результати показують перспективність використання лазерного опромінення світлом у зеленому діапазоні (532 нм) для цілеспрямованої регуляції синтезу білка та біомаси міцелію гриба P. ostreatus.

\section{ЛIТЕРАТУРА}

1. Бисько, Н. А.; Митропольськая, Н. Ю.; Соломко, Э.Ф. Лекарственные грибы - для здоровья и красотыл. Наукова думка: Київ, 2003. $40 \mathrm{c}$.

2. Алексеенко, Е. Н.; Полишко, Т. М.; Винников, А. И. Харчова, лікувальна та екологічна цінність грибів Pleurotus ostreatus. Вісник Дніпропетровського університету. Біологія. Екологія. 2010, 18 (1), с 3-9.

3. Величко, Т. О.; Зубарева, І. М.; Мітіна Н. Б.; Ткаля, О. І.; Шаталін, Д. Б. Оптимізація поживних середовищ для культивування Pleurotus ostreatus. Наукові праиі Одеської нащіональної академії харчових технологій. 2011, 40(2), с 165-167.

4. Friedl, M. A.; Schmoll, M.; Kubicek, C. P.; Druzhinina, I. S. Photostimulation of Hypocrea atroviridis growth occurs due toa crosstalk of carbon metabolism, blue light receptors and response 
tooxidative stress. Microbiology. 2008, 154, pp 12291241.

5. Tisch, D.;

Kubicek, C. P.;

Schmoll, M.

Crossroads between light response and nutrient signalling: ENV1and PhLP1 act as mutual regulatory pair in Trichoderma reese. BMC Genomics. 2014, 15, pp 425-438.

6. Kamada, T.; Sano, H.; $\quad$ Nakazawa, T.; Nakahori, K. Regulation of fruiting body photomorphogenesis in Coprinopsis cinerea. Fungal Genetics and Biology. 2010, 11, pp 917-921.

7. Поєдинок, Н. Енергоефективні системи штучного освітлення у технологіях вирощування їстівних та лікарських грибів. Наука та інноващиї. 2013, 9(3), с 46-59.

8. Дудка, И. А.; Вассер, С. П.; Элланская, И. А. и др. Методь экспериментальной микологии. Справочник. Наукова думка: Київ, 1982. 561 с.
9. Приседський, Ю. Г. Статистична обробка результатів біологічних експериментів. Кассіопея: Донецьк, 1999. 210 с.

10. Приседський, Ю.Г. Пакет програм для проведення статистичної обробки результатів біологічних експериментів. ДонНУ: Донецьк, 2005. $84 \mathrm{c}$.

11. Поєдинок, Н. Л. Биотехнологические основы интенсификации культивирования съедобных и лекарственных макромицетов с помощью света низкой интенсивности: дисс. ... д-ра биол. наук: 03.00.20. Киев, 2015. 387 с.

12. Hillenkamp, F. Interaction between laser radiation and biological systems. Lasers in Biology and Medicine. New York; London, 1987, pp 36-75.

13. Быков, А. В. Лазерная электродинамика, элементарные $u$ когерентные процессы при взаимодействии лазерного излучения с веществом. Физматлит: Москва, 2006, 384 с. 